UDK 346.546(497.6)

Review paper

\title{
COMPETITION LAW IN BOSNIA AND HERZEGOVINA - HOW READY WE ARE FOR THE CHALLENGES OF THE MODERN AGE?
}

\author{
Kanita Imamović-Čizmić, PhD, Associate Professor \\ Faculty of Law, University of Sarajevo \\ Obala Kulina bana 7, 71000 Sarajevo, Bosnia and Herzegovina \\ k.imamovic-cizmic@pfsa.unsa.ba
}

\section{Elma Kovačević-Bajtal, PhD, Director of the Education Department The Foreign Trade Chamber of Bosnia and Herzegovina Branislava Đurđeva 10, 71000 Sarajevo, Bosnia and Herzegovina elma.kovacevic@komorabih.ba}

\author{
Lejla Ramić, MA iur., Teaching and research assistant \\ Faculty of Law, University of Sarajevo \\ Obala Kulina bana 7, 71000 Sarajevo, Bosnia and Herzegovina \\ l.ramic@pfsa.unsa.ba
}

\section{ABSTRACT}

Bosnia and Herzegovina, having an extremely complex state system and at the same time being a developing country and economy in transition with a commitment to membership in the European Union, faces numerous challenges in adapting national legislation to the acquis communautaire. One of the key segments of the introduction of European standards is the establishment of an effective mechanism for the protection of competition in legislative and institutional terms. With the adoption of the Competition Law in 2005, which brings new solutions and is largely in line with the acquis, Bosnia and Herzegovina has made a significant step forward from the previous state of legal irregularity in this important segment. However, sixteen years of the enforcement of the BiH Competition Law have shown certain shortcomings regarding the particular solutions contained in it. These shortcomings concern the part of the provision of the law that regulates procedural issues, but also the functioning of the authority responsible for the protection of competition in Bosnia and Herzegovina and it can be assumed that these are obstructive elements in response to the challenges of COVID-19 pandemic. In order to follow the international trends, companies in BiH have entered into a process of business digitalization, which, however, being accelerated due to COVID-19 pandemic, has created many challenges before the Council of Competition of $\mathrm{BiH}$ as the authority responsible 
for public enforcement of the competition law. The aim of this paper is to question the extent to which COVID-19 pandemic has affected the work of the Council of Competition BiH, as well as to address some of the particular issues it has faced before the pandemic, including growing market concentration, growing power of digital platforms, protectionism, consumer vulnerability and consequent loss of public confidence. In order to meet the set research goals, the first part of the paper will present an analysis of the legal solutions in the context of the legal and institutional aspect of competition protection and will provide an overview of the situation regarding the digitalization of business operations in Bosnia and Herzegovina. The second part of the paper will provide an analysis of the work of the Council of Competition of BiH with special reference to the period of declaring the pandemic COVID-19.

Keywords: competition law, digitalization of the economy, Council of Competition

\section{INTRODUCTION}

In the last few decades, economy has been affected by new digital devices and technologies such as the Internet, wireless broadband communication, and artificial intelligence by changing its classic determinants and turning it into digital. Digital economy based on digital market is recording a structural shift towards an economy characterized by information, intangible assets and services and parallel changes towards new work organizations and institutional forms of economic entities. Digital economy is based on a combination of communications, computing and information. It is based on new business models and new markets, industries. Digital economy is characterized by investments in intangible assets such as knowledge, creativity and innovation. Therefore, the following are important features of digital economy: digitalization and intensive use of information and communication technologies; codification of knowledge; converting information into goods; and new ways of organizing labor and production. ${ }^{1}$ These characteristics of digital economy are reflected in the process of competition in market. Although there is a general view that digital markets result in consumer benefits in the form of lower prices, higher quality and transparency, there is a tendency of digital markets to concentrate. ${ }^{2}$ Indeed, individual digital markets have procompetitive effects in the form of:

1. greater efficiency, in terms of linking supply and demand (e.g., Uber or Amazon);

Kehal S.H.; Singh P.V., Digital Economy: Impacts, Influences and Challenges, Idea group publishing, 2005, p.3

2 Joint report by the FCA and the Bundeskartellamt, Competition law and data, 2016; Joint report by the FCA and the Competition and Market Authority, The economics of open and closed systems, 2014 
2. greater transparency of prices and quality, which facilitates the process of consumer decision-making, lower barriers to market entry because new entrants to digital markets typically face lower fixed costs;

3. creation of two-way platforms that enable interaction of two or more user groups and that lead a large number of users to the platform, which due to network effects result in lower prices. ${ }^{3}$

Given the characteristics of digital markets and changes in competition conditions, the question arises whether the existing legal and analytical tools available to competition authorities are sufficient to address competition law cases in digital economy that have been identified as threats to consumer welfare. In order to find an answer to this question, some researches ${ }^{4}$ have been conducted, the results of which suggest that digital economy has affected the basic categories of competition law and that in this light it is necessary to change the legal and analytical tools used by competition authorities. It is evident that the problem of inadequate legal-analytical instruments in resolving competition-legal cases is faced by the authorities for protection of market competition of developed and less developed countries, but it can be assumed that this problem is more pronounced in less developed countries and countries in transition. The results of the mentioned studies were a motivating factor for writing this paper, which aims to examine whether the Council of Competition, as the authority responsible for the enforcement of competition law in Bosnia and Herzegovina, faces challenges related to resolving competition law cases under the conditions of digital economy, which are supposed to be more pronounced due to the work in the circumstances of COVID-19 pandemic, whether it recognizes certain problems and how it sees their solution. The paper consists of a theoretical framework of the problem in which relevant facts are presented, including the process of digitalization of economy in $\mathrm{BiH}$, and an analysis in which a comparative method will answer the question of how ready the Council of Competition is for the challenges of digital economy.

Honoré P.; Verzeni R., Competition law in the digital economy: a French perspective, Antitrust \& Public Policies, Vol 4, No 2, 2017, p. 86

4 Crémer, J.; de Montjoye Y-A.; Schweitzer, H., Competition Policy for the digital era, Final report. Luxembourg: Publications Office of the European Union, 2019, [https://www.bibsonomy.org/bibtex/2f87b8251c8f49b69fd7bddedec8a7a49/meneteqel], Accessed 15 March 2021

Van Gorp, N.; Batura, O., Economic and scientific policy: Challenges for Competition Policy in a Digitalised Economy Study, Directorate general for internal policies policy department, 2015, [https://www. europarl.europa.eu/RegData/etudes/STUD/2015/542235/IPOL_STU(2015)542235_EN.pdf], Accessed 15 March 2021

World Economic Forum, White paper: Competition Policy in a Globalized Digitalized Economy, 2019, [http://www3.weforum.org/docs/WEF_Competition_Policy_in_a_Globalized_Digitalized_Economy_Report.pdf], Accessed 15 March 2021 


\section{DIGITIZATION OF ECONOMY AND CHALLENGES OF COMPETITION LAW}

Competition law represents the totality of legal regulations that protect market competition in its trichotomous meaning. Provisions of competition law prohibit socially harmful behavior that restricts, prevents or distorts market competition that reduces positive effects on consumers, producers, the state and economic development of a community in general. The indicated socially harmful behaviors refer to certain business practices that economic entities demonstrate on traditional markets. However, digitalization of economy has imposed digitalization of business processes and spawned digital markets, thus creating the need to reconceptualize the classical notion of market and consequently open a number of regulatory issues. One of the questions that has been raised and on which some studies $^{5}$ have been conducted is whether the existing regulatory framework and the legal instruments based on it are adequate to protect competition in digital market. ${ }^{6}$ The issues occupy a significant place in the debates of highly developed countries and countries that have inherited a competitive legal culture for centuries, but the question should be raised about less developed countries which have gone through a transition period and do not have extensive experience in modern competition law. Do the competition authorities in these countries recognize the danger of inadequately resolving competition law cases with elements of digitization in the current regulatory environment? Are they ready for the challenges of resolving such cases? Is their challenge greater in the face of COVID-19 pandemic, which may have accelerated the processes of digitalization of their economies? Previous researches have not highlighted this angle of observation or singled out this target group. It is almost clear that COVID-19 pandemic accelerated the process of digitalization of business in this group of countries and thus opened a space for transactions through digital markets, which undoubtedly creates the preconditions that make "digital cases" appear before the competition authorities.

\section{DIGITIZATION OF BUSINESS IN BIH - COVID-19 AS AN ACCELERATOR OF DIGITIZATION OR NOT?}

Recent findings from a study by a group of authors $(2019)^{7}$ say that "most companies currently have little or no internal technological knowledge in the field of

Akman P. Online Platforms, Agency, and Competition Law: Mind the Gap. Fordham Int'l LJ, Vol. 43, No 2, 2019. Crémer; de Montjoye; Schweitzer, op. cit., note 4.

6 Imamović-Čizmić K., Digital economy, new concepts of competition of economic entities and challenges to competition law and policy, Yearbook of the Law Faculty of the University of Sarajevo, LXIII, 2020, p. 157 Burks J.; Šipragić M.; Bogunović S., Information and communication technology-fuel for SME competitiveness, Deutsche Gesellschaft für Internationale Zusammenarbeit (GIZ), Sarajevo, 2019, p. 40 
ICT, digitalization and 4.0 industry". Research shows that, although aware of the importance of digital business transformation, many companies, even before COVID-19 pandemic burdened with everyday business problems, do not have a clear picture of what digitalization entails, nor how much investment in equipment and knowledge is needed to make the transformation happen. In our case, this means that, in order to maintain their competitiveness, our manufacturing companies should update their processes and introduce digital solutions. "The companies in $\mathrm{B} \& \mathrm{H}$ mostly produce homogeneous products that are easily substitutable. So far, they have been able to hold their own in international markets due to comparatively low prices and good to high product quality. The profound transformation due to digitalization will hit production companies, in particular, those not prepared for the digital transformation and sticking to traditional methods. Digital transformation optimizes processes, changes structures and organizations in companies." Digital transformation encompasses many areas such as digital marketing, digitalization and automation of business processes, business models, sales channels, digital procurement, Big Data. ${ }^{9}$ Of course, there are many other processes associated with multidimensional transformation of companies. According to David L. Rogers, digital transformation is based on five different areas, which include consumers, competition, value, innovation and data. ${ }^{10}$ In short, digital transformation is in the function of using technology and data with the aim of creating new products and services, as well as placing them on domestic and international market. Practically, and according to the findings of the profession that follows the trend of digitalization in the field of production and consumption, digitalization opens the possibility for companies to develop new business models and new customer groups and existing markets through innovation. Digitalization creates new products that, for example, contain services and data. ${ }^{11}$ However, the change in business conditions caused by the pandemic requires a rapid change of opinion and creation of new priorities in the business of each company. Although it has been previously considered that digitalization requires preparation time, significant investment in equipment and knowledge, at the beginning of the pandemic the situation took on an urgent character: it ceased to be just one of the future activities and became a test of business sustainability and company survival. Purposeful research of this kind shows that companies from Bosnia and Herzegovina, under the conditions of conducting business during the pandemic, see digital transformation as one of the most important and inevitable solutions in the new

\footnotetext{
$8 \quad$ Ibid.

9 Jashari E., The impact of COVID-19 on digital transformation, Digital transformation - a pillar of economic recovery, Kosovo Chamber of Commerce and Konrad Adenauer Foundation, 2020, p. 7

10 Ibid.

11 Burks; Šipragić; Bogunović, op. cit., note 7, p. 41
} 
conditions of their operations. Because, "digital transformation means transforming the mentality of companies so that the use of digital tools and skills adds value and creates a competitive advantage". ${ }^{12}$ In this sense, "the company's individual digitalization strategy forms the basis for the company's digital transformation". ${ }^{13}$

International organizations are also involved in supporting the digitalization of companies in $\mathrm{BiH}$, among which UNDP has been particularly engaged through its DigitalBIZ project. The DigitalBIZ project evaluates the digital performance and readiness of companies through the online tool "Digital Pulse". ${ }^{14}$ The project envisages cooperation with business development service providers in order for these organizations to improve their service offer in the level of demanding and dynamic market relations of our time. In accordance with its vision and mission, being guided by the goal of raising awareness of the importance of digitalization, information and education of entrepreneurs on the importance of digitalization and its easier and faster application in practice, the Foreign Trade Chamber has organized two conferences ${ }^{15}$, prepared the edition Digitalization of the $\mathrm{BiH}$ Economy, and held numerous trainings. In addition, the Foreign Trade Chamber, as an economic association, realizing the current importance of digitalization of business, launched a project with a nominally symptomatic, i.e. practically indicative name and a clear message - "Digital Chamber". ${ }^{16}$ However, for the right application of digitalization in practice, it is necessary to understand the digitalization of business on the basis of identified shortcomings of the digital capacity of enterprises in Bosnia and Herzegovina. Ultimately, DigitalBIZ plans to imple-

12 Jashari E, op. cit., note 9

13 Burks; Šipragić; Bogunović, op. cit., note 7, p. 43

14 UNDP BiH in cooperation with the Luxembourg Chamber of Commerce, About us, [https://www. digitalnaekonomija.ba/bs-Latn-BA/about], Accessed 12 April 2021

15 Oslobođenje, Digitalizacija društva je nasušna potreba, [https://www.oslobodjenje.ba/vijesti/bih/digitalizacija-drustva-je-nasusna-potreba-418240], Accessed 31 March 2021. One of the speakers at the conferences was dr. Vjekoslav Vuković, Vice President of the Foreign Trade Chamber of BiH, who said: "Digitalization is greater transparency and greater transparency in business, i.e., the speed of information exchange, is greater competitiveness."

16 Foreign Trade Chamber of Bosnia and Herzegovina, Digitalna komora, Vrata u budućnost, [https:// www.komorabih.ba/?s=digitalna+komora], Accessed 01 April 2021. "The Digital Chamber is conceptually conceived as an online ecosystem of a multifunctional character that enables the integration of all business-relevant data in Bosnia and Herzegovina, but also for $\mathrm{BiH}$ business entities on the international business scene. In this context, the digital chamber primarily enables users to participate in a digital, online environment, that combines data on all $\mathrm{BiH}$ producers, both management in the ownership and management context, and financial or business with all the essential features of product ranges, prices, deadlines, etc. In this light, the digital chamber integrates data in one place from several internal (the business entity and its business partners) and external sources (a whole range of data collection and publication agencies both at the macro level, i.e., the level of the economy, and at the micro business level or in relation to a specific business entity).” 
ment support measures for the digitalization of micro, small and medium-sized enterprises, including training and mentoring, and to provide incentives for digital transformation of their business. ${ }^{17}$

In order for each company to determine the situation, opportunities and its own readiness to introduce digital transformation, The United Nations Development Program, within the DigitalBiz Project, has activated the Digital Pulse, an electronic service that provides companies in Bosnia and Herzegovina with the opportunity to self-assess their digital maturity according to predefined questions and criteria. Based on the responses given by companies to the structured questionnaire, Digital Pulse generates basic recommendations for digitization in six business areas of companies. The information obtained through this tool will be used for better planning of support to the activities of both domestic and international partners in the field of digital transformation of the private sector in Bosnia and Herzegovina. ${ }^{18}$ The development of experts at the enterprise level, the qualification and retraining of available staff for the use of digital technologies are key practical steps for successful digital transformation of any company. The new way of doing business, caused by the pandemic, did not leave enough time for the necessary preparation and implementation of the digital transformation. Due to the limited movement of people and goods, without significant preparations, where preconditions for that were present, flexible work organizations were created: work in virtual groups, established way of crisis communication, formed crisis teams, etc., which resulted in increased competition and self-organization in accordance with its own responsibility. Of course, digital transformation implies significant financial investments in equipment and acquisition of specific knowledge in this area. Introduction of digitalization implies continuous work on improving the internal and external processes of each company. It could be expected, and particularly so under the conditions of the pandemic (which will obviously take time), digitalization should improve the innovative capacity of companies, which contributes to the development of new, innovative business models. ${ }^{19}$ In that sense, digitalization is not treated as a mode of buying a new technological device, but quite the opposite: as a process of transformation and a good opportunity to reduce operating costs. Among other things, and as already mentioned, digitalization was used to prepare companies to be more competitive in domestic and foreign

\footnotetext{
17 UNDP BiH, op. cit., note 14

$18 \mathrm{BiH}$ Chamber of Foreign Trade, UNDP: Notification on activation of tools for assessment of digital performance of companies in Bosnia and Herzegovina (Digital Pulse), [https://www.komorabih.bal undp-obavijest-o-aktiviranju-alata-za-procjenu-digitalnih-performansi-kompanija-u-bosni-i-hercegovini-digitalni-puls/], Accessed 25 March 2021

$19 \quad$ Ibid. p. 58
} 
markets. ${ }^{20}$ Studies show that the main obstacles hindering the digitalization process of companies are the following: lack of digital skills of the workforce, lack of technical knowledge for further progress of the digitalization process and lack of or access to finance. ${ }^{21}$ However, many have used the covid-crisis as a catalyst for a future-oriented recovery. At the same time, digital transformation means much more than full integration of digital technologies. In the socio-psychological sense, digital transformation implies a specific internal change - transformation - of the mentality of companies, so that, in the professional register, the use of digital tools and skills adds value and creates a competitive advantage. ${ }^{22}$

Finally, there is no doubt that COVID-19 pandemic has accelerated the process of digital transformation of companies ${ }^{23}$, making them treat it not only as an additional possibility, but also as a realistic, inevitable solution to the problem of their own survival. Ergo: digitalization has grown into an innovative mode that, with the power of its internal logic, makes it faster, more successful and more competitive in domestic and foreign markets.

\section{REGULATORY FRAMEWORK FOR COMPETITION PROTECTION IN BIH}

Bosnia and Herzegovina, as a developing country with economy in transition with a small open market, introduces a modern regulatory framework for the protection of competition with the 2001 Law on Competition. Until 2001, competition law and policy did not exist at the state level ${ }^{24}$, but only certain institutes of competition law and policy were regulated in isolation and unsystematically within only a few provisions of the entity Trade Laws. These first steps towards creating a modern regulatory framework for market competition are the result of foreign pressure expressed through the development of the project titled "Single Economic Space in BiH". However, the $2001 \mathrm{Law}$ on Competition had a number of limitations: the constitutional division of competencies between the state and the entities, a low level of integration of Bosnia and Herzegovina's economic space, underdeveloped institutions, locating competition and consumer protection at the entity level in the same body - the Office for Competition and Consumer Protection, very scarce substantive-legal regulation of monopolistic activity, including

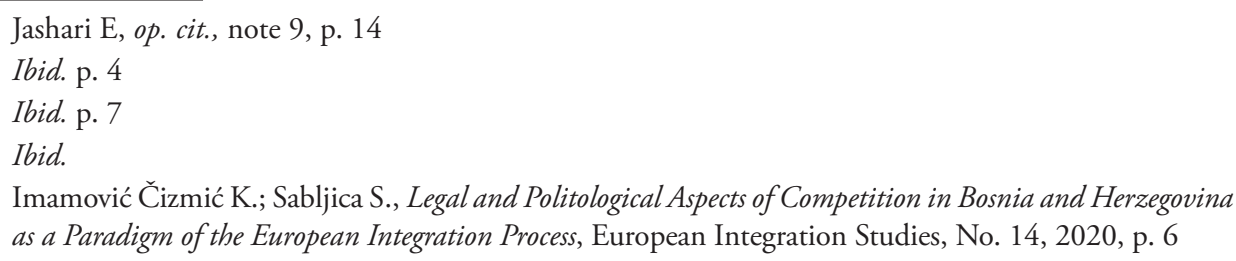


a new institute - concentration control, and the complete absence of sanctions for anti-competitive acts. This law is considered a failed attempt to transfer the European Union competition rights to the system of Bosnia and Herzegovina. ${ }^{25}$

These restrictions have created the need for a new competition law that will be in line with the European Union competition law. Pursuant to Article IV, paragraph 4a) of the Constitution of Bosnia and Herzegovina, the Parliamentary Assembly of Bosnia and Herzegovina at its session of the House of Peoples, held on June 29, 2005, and at the session of the House of Representatives, held on June 29, 2005, adopted the Law on Competition. ${ }^{26}$ It was the first official legal act that followed the practice and solutions of the modern European legislation - the legal heritage of the European Union, adopted in order to fulfill obligations on the path to European integration. The Competition Law is largely compatible with the rules and regulations of the European Union in the field of market competition. The enforcement of the Law on Competition should result in greater efficiency and transparency in the procedure of protection of market competition in Bosnia and Herzegovina, in terms of simplification of procedures, shortening the duration of certain stages of the procedure, etc. The law regulates certain issues in principle and leaves room for the Council of Competition to define them more precisely. In view of this fact, the Council of Competition has adopted a number of bylaws that follow the decisions of the European Union and are in line with the acquis communautaire. ${ }^{27}$

The main goal of the Law on Competition is to protect market competition in Bosnia and Herzegovina, strengthen and establish a single market at the state level, which should ultimately result in increased consumer welfare in the $\mathrm{BiH}$ market. The Law contains 62 articles, systematized in four chapters, which prescribe the rules, measures and procedure for the protection of market competition and com-

25 Trifković M., Defining monopolistic agreements of laws in Bosnia and Herzegovina and European Union, Pregled - Journal for Social Issues, Vol. 4, LXXXVI, 2006, p. 63

26 Law on Competition, Official Gazette of BiH No. 48/05, 76/07 and 80/09

27 Regulation on the procedure of release or mitigation of punishment (leniency policy); Regulation on the manner of submitting the application and criteria for assessing concentrations of economic entities; Regulation on small value agreements; Regulation on amendments to the Decision on small value agreements; Regulation on determining the relevant market; Regulation on block exemption of agreements between economic entities operating at the same level of production or distribution (horizontal agreements), which specifically relate to research, development and specialization; Regulation on the block exemption of technology transfer agreements, licenses and know-how; Regulation on block exemption of insurance agreement; Regulation on defining the categories of dominant position; Regulation on block exemption of agreements between economic entities operating at different levels of production or distribution (vertical agreements); Regulation on block exemption of agreements on distribution and servicing of motor vehicles. Available at: Council of Competition, Bylaws, [http:// bihkonk.gov.ba/en/category/legislation/bylaws, Accessed: 21 June 2021 
petencies and the manner of work of the Council of Competition on the protection and promotion of market competition in Bosnia and Herzegovina. Although the adoption of the Competition Law has made a significant step forward in relation to the state of complete irregularity, it has certain shortcomings, primarily in the provisions of the procedural type, namely those governing the formation and decision-making of the Council of Competition. It is hoped that they will be eliminated by adopting amendments to the law for which the Working Group of the Council of Competition was formed in August 2020.

\section{COUNCIL OF COMPETITION - WORK UNDER THE CONDITIONS OF COVID-19 AND THE CHALLENGES OF THE DIGITAL AGE}

The Council of Competition, as an autonomous and independent body with the status of a legal entity, is responsible for the implementation of the competition law in terms of exclusive authority in deciding on the existence of anti-competitive behavior on the market of Bosnia and Herzegovina. ${ }^{28}$ The Competition Council includes the Competition Offices in the Federation of Bosnia and Herzegovina and Republika Srpska, as organizational units outside the seat of the Competition Council in Sarajevo. Since the establishment of the Council of Competition until today, the enforcement of the competition law has more precisely defined its competencies in performing administrative and professional tasks related to various aspects of protection of market competition and the manner of conducting the procedure. ${ }^{29}$ However, there are still certain solutions in the law that negatively affect the efficiency of the work of the Council of Competition.

The financing model of the Competition Council is determined by the Law on Competition in such a way that the funds for the implementation of competencies and performance of the activities of the Council of Competition are provided from the Budget of the institutions of Bosnia and Herzegovina. ${ }^{30}$

Article 22 of the Law on Competition ${ }^{31}$ determines the composition of the Council of Competition, which consists of six members. Such legal solution, in terms of the number of members, is unusual and complicates the decision-making process of the body itself. Members are elected from among recognized experts in the relevant field, have a status equal to administrative judges that is incompatible with

\footnotetext{
28 Council of Competition of Bosnia and Herzegovina, Competencies and organization, [http://bihkonk. gov.ba/nadleznosti-i-organizacija], Accessed 10 April 2021

29 Ibid.

30 Ibid.

31 Official Gazette of BiH No. 48/05, 76/07 and 80/09
} 
the performance of any direct or indirect, permanent or periodical function, with the exception of academic activities and work in professional and scientific bodies for a term of six years with the possibility of re-election. ${ }^{32}$

The complexity of the constitutional and legal system, which implies the existence of political determinism in Bosnia and Herzegovina, is reflected both in the election of members of the Council of Competition and in the decision-making process in competition law cases.

According to the mentioned article of the Competition $\mathrm{Law}^{33}$, the appointment of the members of the Council of Competition is carried out as follows:

a) Three members are appointed by the Council of Ministers of Bosnia and Herzegovina, one from each of the three constituent peoples;

b) Two members are appointed by the Government of the Federation of Bosnia and Herzegovina;

c) One member is appointed by the Government of Republika Srpska.

The Council of Ministers of Bosnia and Herzegovina, at the proposal of the Council of Competition, appoints each year a president from among the members of the council for a period of one year, without the right to re-election during the term of office of a member of the Council of Competition. ${ }^{34}$

According to Article 24 of the Competition Law, the Council of Competition may make valid decisions if at least five members of the council are present at the session, and decisions are made by a majority vote of the members present, provided that at least one member from the constituent peoples votes for each decision. ${ }^{35}$

32 Article 22 (2) of the Law on Competition, Official Gazette of BiH No. 48/05, 76/07 and 80/09

33 Article 22 (3) of the Law on Competition, Official Gazette of BiH No. 48/05, 76/07 and 80/09

34 Council of Competition, op. cit., note 28

35 The Constitutional Court of Bosnia and Herzegovina in plenary session, in case number U 25/14, resolving the request of Željko Komšić, at the time of submitting the request of the member of the Presidency of Bosnia and Herzegovina, pursuant to Article VI.3. a) of the Constitution of Bosnia and Herzegovina, Article 57 para. (2) indent b) and Article 59 para. (1) and (3) Rules of the Constitutional Court of Bosnia and Herzegovina - Consolidated text, Official Gazette of Bosnia and Herzegovina No. 94/14, at its session held on July 9, 2015, issued a Decision on admissibility and merits according to which it refused Željko Komšićs request for review of the constitutionality of Article 22, paragraph (3), item a) and Article 24, paragraph (2) of the Law on Competition, Official Gazette of Bosnia and Herzegovina No. 48/05, 76/07 and 80/09. The Court found that Article 22 paragraph (3) item a) and Article 24 paragraph (2) of the Law on Competition, Official Gazette of Bosnia and Herzegovina No. 48/05, 76/07 and 80/09, were in accordance with with Article II/4 of the Constitution of Bosnia and Herzegovina and Article 1 of Protocol No. 12 to the European Convention for the Protection of Human Rights and Fundamental Freedoms 
A member of the council may not abstain from voting. ${ }^{36}$ The obligation that "at least one representative of each constituent peoples" must vote for the decision is a major anomaly because in practice there may be a situation that no decision can be made in a particular case, which is considered to have given tacit consent to the applicant e.g. to the company that filed a request to determine that it was not abusing its dominant position. Namely, according to Article 11 paragraph (2) of the Law on Competition, if the Council of Competition has not issued a decision within the period referred to in Article 41 paragraph (1) item c), it is considered that the concluded agreement or conduct of the business entity does not abuse the dominant position. ${ }^{37}$ This can have unforeseeable consequences for competition on the $\mathrm{BiH}$ market because if two members of the two constituent peoples vote "for" and two members of the third constituent people vote "against", the decision cannot be made, which can be treated as a veto. ${ }^{38}$ The specificity of the Competition Act also refers to Article 41, which regulates the duration of the procedure. The procedure for determining the violation of rights should not be limited in time, although it is prescribed by law when it comes to prohibited agreements, determining certain exemptions, abuse of a dominant position and determining the assessment of concentration. ${ }^{39}$

The competence of the Council of Competition is determined by Article 25 of the $\mathrm{Law}^{40}$ in such a way that the Council of Competition:

a) issue regulations pursuant to the provisions of the Competition Law and other regulations for its enforcement;

b) prescribe definitions and calculation methods for specific activities i.e. banking, insurance, etc.;

c) prescribe and provide interpretation of general and specific definitions of the competition terms, as well as calculation methods for the key competition terms;

d) decide on claims for the initiation of proceedings and conduct the proceedings;

e) issue administrative acts to finalize a proceeding before the Competition Council;

\footnotetext{
36 Article 24 (2) of the Law on Competition, Official Gazette of BiH No. 48/05, 76/07 and 80/09

37 The Report on the work of the Council of Competition for 2018 just states that one decision on the concentration was not made because the conditions from Article 24 of the Law on Competition, Official Gazette of BiH No. 48/05, 76/07 and 80/09, were not met.

38 Imamović Čizmić K.; Sabljica S., op. cit., note 24, p. 9

39 Ibid. p. 6

40 Official Gazette of $\mathrm{BiH}$ No. 48/05, 76/07 and 80/09
} 
f) provide opinions and recommendations on any aspect of competition, either ex officio or at the request of the state authorities, undertakings or associations;

g) issue internal acts on the internal organization of the Competition Council, except for the Rule-book on the internal organization and systematization which shall be issued with the approval of the Council of Ministers of Bosnia and Herzegovina;

h) initiate amendments to the Law on Competition;

i) propose to the Council of Ministers of Bosnia and Herzegovina the Decision on the amount of administrative taxes relating to the procedural actions before the Competition Council.

The Council of Competition reports on its work to the Council of Ministers of Bosnia and Herzegovina, which, after its adoption, publishes the Report in public. ${ }^{41}$ In proceedings before the Council, unless otherwise prescribed by law, the Law on Administrative Procedure shall apply. ${ }^{42}$ The Council of Competition shall initiate proceedings ex officio, if there is a reasonable suspicion that market competition is significantly prevented, restricted and distorted, or upon the request of a party. ${ }^{43} \mathrm{~A}$ request to initiate proceedings, in accordance with the provisions of the law, may be submitted by: a) any legal or natural person having a legal or economic interest; b) chambers of commerce, associations of employers and entrepreneurs; c) consumer associations; d) executive authorities in Bosnia and Herzegovina. ${ }^{44}$

The law therefore regulated the procedure before the Council. Thus, in procedural terms, the procedure is initiated on the basis of the Council's Conclusion to initiate the procedure ex officio or after receiving the request, after which the Council appoints a responsible member who manages the procedure and appoints an official in charge of conducting the procedure. ${ }^{45}$ In the investigation procedure, the law gave certain powers to the Council and provided for the obligation for parties and other legal and natural persons to provide all the required information in the form of written motions or oral statements and submit necessary data and documents for inspection, regardless of the type of the media. ${ }^{46}$ Also, according to the law, the parties must enable direct access to all business premises, movable and im-

\footnotetext{
41 Article 25 (5) of the Law on Competition, Official Gazette of BiH No. 48/05, 76/07 and 80/09

42 Official Gazette of BiH, No. 29/02

43 Article 27 (1) of the Law on Competition, Official Gazette of BiH No. 48/05, 76/07 and 80/09

44 Article 27 (2) of the Law on Competition, Official Gazette of BiH No. 48/05, 76/07 and 80/09

45 Article 34 (1) of the Law on Competition, Official Gazette of BiH No. 48/05, 76/07 and 80/09

46 Article 35 of the Law on Competition, Official Gazette of BiH No. 48/05, 76/07 and 80/09
} 
movable property, business books, databases and other documents, and in doing so they shall not be prevented by any business, state or technical secret. ${ }^{47}$ The parties are obliged to submit the necessary information and notifications about other persons that may contribute to solving and explaining certain issues on prevention, limitation or distortion of competition and enable other necessary actions with the aim of establishing all the relevant facts in the proceedings. ${ }^{48}$ During the proceedings, the Council is obliged to provide access to the file, keep business secrets and conduct an oral hearing in cases when the proceedings were initiated at the request of the parties. ${ }^{49}$ This obligation is a reflection of the promotion of the principles of transparency but also the protection of data confidentiality, which also contributes to legal security. Also, the Council may issue a decision on an interim measure, based on a preliminary violation, if it considers that certain actions prevent, restrict or distort market competition, threaten the emergence of direct harmful effects for certain economic entities, or certain branches of economy or consumer interests. ${ }^{50}$ The duration of the proceedings before the Council is limited by the statutory time limit depending on the very nature of the case. ${ }^{51}$ The Council may not issue a final decision, in cases where it deems that additional expertise or analysis is necessary to establish the facts and assess the evidence, or in the case of sensitive industries or markets. ${ }^{52}$ Then the deadline for making a final decision can be extended up to three months, whereby it is obligatory to inform the parties on the decision in writing. ${ }^{53}$ After the completion of the procedure, the responsible member of the Council submits a report on the conducted procedure with a proposal for a decision, and at the session a final decision is made whether there is a violation of the law. The dissatisfied party in the procedure may initiate an administrative dispute before the Court of Bosnia and Herzegovina within 30 days from the receipt of the decision, i.e., from the day of publication of the decision. ${ }^{54}$

Competition law cases are related to certain behaviors of economic entities in an economic process, in a particular market. In theory, the correlation between the level of economic development, the available budget and the efficiency of public enforcement of competition law has been proven. With this in mind, it is neces-

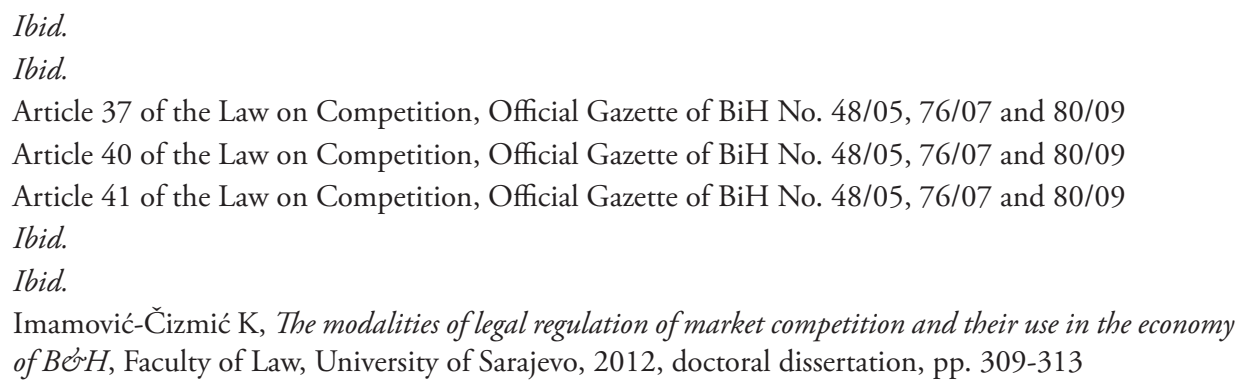
of B⿺ $H$, Faculty of Law, University of Sarajevo, 2012, doctoral dissertation, pp. 309-313 
sary to point out that $\mathrm{BiH}$ is a small, open economy whose GDP in 2020, according to the World Bank, amounted to 20,164.19 million US dollars and GDP per capita 6,108.5 US dollars. ${ }^{55}$ Analyzing the work of the Council on individual cases for the reference period 2016-2020, it can be concluded that most cases were in the area of concentration of economic entities and that there is no change in the trend of resolving cases related to prohibited agreements and abuse of dominant position. If the work of the Council of Competition is compared with the work of the competition authorities of Serbia, Montenegro, North Macedonia, Croatia and Slovenia (Table 2 - Table 6$)^{56}$ then it can be stated that the trends in resolving individual cases are almost the same, indicating three important facts:

1. all the above-mentioned states had the same competition law heritage from the period when they were part of the Socialist Federal Republic of Yugoslavia (SFRY),

2. all these countries do not have the same degree and trend of growth, i.e., economic development or the size of national markets after the dissolution of the SFRY,

3. Slovenia and Croatia are members of the European Union and therefore their competition authorities apply the Union rules in accordance with Council Regulation (EC) no. 1/2003. on the implementation of the rules on competition laid down in Articles 81 and 82 of the EC Treaty.

Table 1: Number of decisions of the Council of Competition on individual cases in $\mathrm{BiH}^{57}$

\begin{tabular}{|l|c|c|c|c|c|}
\hline Case & 2016 & 2017 & 2018 & 2019 & 2020 \\
\hline Concentrations & 11 & 12 & 24 & 12 & 12 \\
\hline Prohibited agreements & $6^{58}$ & 5 & $4^{59}$ & - & $1^{60}$ \\
\hline Abuse of a dominant position & $6^{61}$ & 1 & 2 & 1 & $3^{62}$ \\
\hline
\end{tabular}

55 World bank, GDP per capita, [https://data.worldbank.org/indicator/NY.GDP.PCAP.CD?view=chart], Accessed on, 01 April 2021

56 The methodology of compiling the work report differs in the countries, which was a limiting factor in the presentation of statistical data. The annual reports of the Kosovo Council of Competition cannot be accessed through the website

57 Reports on the work of the Council of Competition of Bosnia and Herzegovina, [http://bihkonk.gov. ba/], Acceseed 21 March 2021

58 The Report provides a summary of resolved cases for both types of prohibited conduct

59 Two decisions were made to suspend the proceedings

60 One request to establish a prohibited agreement has been suspended

61 The Report provides a summary of resolved cases for both types of prohibited conduct

62 Three requests for determining the abuse of a dominant position were left, and one request related to both prohibited competitive actions was also suspended 
Table 2: Number of decisions issued by the Croatian Competition Agency in individual cases in the Republic of Croatia ${ }^{63}$

\begin{tabular}{|l|c|c|c|c|c|}
\hline Case & $2016^{64}$ & 2017 & $2018^{65}$ & 2019 & $2020^{66}$ \\
\hline Concentrations & 16 & $14^{67}$ & & 34 & \\
\hline Prohibited agreements & 5 & 3 & 10 & 25 & \\
\hline Abuse of a dominant position & $2(33)^{68}$ & 2 & - & 22 & \\
\hline
\end{tabular}

Table 3: Number of adopted decisions of the Agency for Protection of Competition of Montenegro by individual cases in the Republic of Montenegro ${ }^{69}$

\begin{tabular}{|l|c|c|c|c|c|}
\hline Case & 2016 & 2017 & 2018 & $2019^{70}$ & $2020^{71}$ \\
\hline Concentrations & $23^{72}$ & $27^{73}$ & $40^{74}$ & & \\
\hline Prohibited agreements & 3 & $4^{75}$ & 1 & & \\
\hline Abuse of a dominant position & 2 & $1^{76}$ & $--^{-77}$ & & \\
\hline
\end{tabular}

63 Reports on the work of the Croatian Competition Agency, [http://www.aztn.hr/godisnja-izvjesca/], Accessed 22 March 2021

64 The Annual Report on the Work of the Croatian Competition Agency states the total number of administrative cases resolved in 2016 - 56. The numbers per resolved cases are not completely stated.

65 The Report states that the work of the Croatian Competition Agency was interrupted in the period from November 15, 2018 to January 25, 2019. Namely, on November 15, 2018, the mandate of three members of the Council expired, and the Croatian Parliament appointed new members on January 25, 2019

66 The Annual Report of the Croatian Competition Agency for 2020 is not available, [http://www.aztn. hr/godisnja-izvjesca/], Accessed 22 March 2021

67 The exact number is not stated in the Annual Report on the number of resolved cases

68 In 33 cases, after a detailed examination of the situation on the relevant market, the Agency rejected the applicant's initiatives by a decision because there were no conditions for initiating proceedings in the sense of the Competition Act

69 Reports on the work of the Agency for Protection of Competition of Montenegro, [http://www.azzk. $\mathrm{me} / \mathrm{jml} /$ index.php/ostala-dokumenta/izvjestaji/izvjestaji-o-radu], Accessed 22 March 2021

70 The 2019 Work Report is not available on the website [http://www.azzk.me/jml/index.php/ostala-dokumenta/izvjestaji/izvjestaji-o-radu], Accessed 22 March 2021

71 The 2020 Work Report is not available on the website [http://www.azzk.me/jml/index.php/ostala-dokumenta/izvjestaji/izvjestaji-o-radu], Accessed 22 March 2021

72 The number indicates the decisions made based on the 2016 request. The total number of resolved cases in 2016 was 29 , counting the transferred requests from 2015

73 The number indicates the decisions made based on the 2017 request. The total number of resolved cases in 2017 was 48, counting the transferred requests from 2016

74 The number indicates the decisions made based on the request from 2018. The total number of resolved cases in 2018 is 38, counting the transferred requests from 2017

75 Two decisions were made on the request for individual exemption of the agreement from the ban

76 The work report contains information on further actions in cases in which the Agency's Decisions were previously issued

77 The Report on Work for 2018 lists further actions in cases for which a decision was made in 2017 
Table 4: Number of adopted decisions of the Commission for Protection of Competition in individual cases in the Republic of Serbia ${ }^{78} 7980818283$

\begin{tabular}{|l|c|c|c|c|c|}
\hline Case & 2016 & 2017 & 2018 & 2019 & $2020^{79}$ \\
\hline Concentrations & 111 & 148 & 166 & 197 & \\
\hline Prohibited agreements & $5^{80}$ & $5^{81}$ & $5^{82}$ & $3^{83}$ & \\
\hline Abuse of a dominant position & 3 & 3 & 2 & 7 & \\
\hline
\end{tabular}

Table 5: Number of decisions issued by the Slovenian Competition Protection Agency in individual cases in the Republic of Slovenia ${ }^{84}$

\begin{tabular}{|l|c|c|c|c|c|}
\hline Case & 2016 & $2017^{85}$ & $2018^{86}$ & $2019^{87}$ & $2020^{88}$ \\
\hline Concentrations & 34 & 26 & 41 & 32 & \\
\hline Prohibited agreements & $1^{89}$ & 2 & 1 & 2 & \\
\hline Abuse of a dominant position & - & 1 & 1 & - & \\
\hline
\end{tabular}

78 Reports on the work of the Commission for Protection of Competition of the Republic of Serbia, [http://www.kzk.gov.rs/izvestaji], Accessed 22 March 2021

79 The Report on the work of the Commission for Protection of Competition is not available

8021 decisions were made in the procedure for individual exemption of restrictive agreements from the ban

8130 decisions were made in the procedure for individual exemption of restrictive agreements from the ban

8222 decisions were made in the procedure for individual exemption of restrictive agreements from the ban

8328 decisions were made in the procedure for individual exemption of restrictive agreements

84 Reports on the work of the Slovenian Competition Protection Agency, [http://www.varstvo-konkurence. si/en/activities-of-the-agency/reports-and-activities/], Accessed 22 March 2021

85 The Agency made two more decisions on the termination of the procedure, one from the domain of abuse of dominant position, and the other from concentration

86 A decision was also made to terminate the proceedings in the area of restrictive practices. In a separate procedural misdemeanor procedure, two misdemeanor decisions were made against the offenders of the legal entity and the responsible person in the field of competition protection

87 Two decisions were also made to suspend the proceedings, in the field of concentration assessment. In a separate procedural misdemeanor procedure, three misdemeanor decisions were issued against infringers of legal entities and responsible persons in the field of competition protection

88 The Report on the work of the Slovenian Competition Protection Agency is not available on the website [http://www.varstvo-konkurence.si/en/activities-of-the-agency/reports-and-activities/], Accessed 22 March 2021

89 Two decisions on suspension of the procedure were made 
Table 6: Number of decisions of the Commission for Protection of Competition by individual cases in the Republic of North Macedoni $a^{90}$

\begin{tabular}{|l|c|c|c|c|c|}
\hline Case & 2016 & 2017 & 2018 & $2019^{91}$ & $2020^{92}$ \\
\hline Concentrations & 31 & 50 & 61 & & \\
\hline Prohibited agreements & 3 & 6 & 4 & & \\
\hline Abuse of a dominant position & 2 & 1 & 2 & & \\
\hline
\end{tabular}

\subsection{Comparative presentation of the perception of the work of the competition authorities for protection of market competition in the conditions of digital economy}

The research was conducted in March 2021. In order to reach the set goal, i.e. to examine the perception and work of the Council of Competition using a comparative method, a survey was sent to the competition authorities for protection of competition in Serbia, Montenegro, North Macedonia, Kosovo, Croatia, Slovenia and Bosnia and Herzegovina. The reason why the mentioned countries were chosen is situated in the previously mentioned facts: the same legacy of competition, different level of economic development and growth rate after the dissolution of the SFRY and the fact that two of them are members of the EU. The survey contained 22 questions with a Likert scale of answers and was designed to examine experiences in working on competition law cases related to digital platforms, and to provide a perception of people working on these cases in terms of the adequacy of existing tools and improvements in the functioning of their bodies. The survey was completed by a total of 6 respondents, 4 of which were from $\mathrm{BiH}$ and 2 from Serbia, which is not a relevant sample for the research because it is estimated that in the competition authorities of these countries more than 100 employees work on solving the cases.

\section{INSTEAD OF CONCLUSION}

COVID-19 pandemic has certainly affected all spheres of social life, from education and culture to economy. It has influenced the change of the economic process itself, which we are witnessing ourselves as we are increasingly buying via the

\footnotetext{
90 Reports on the work of the Commission for Protection of Competition, [http://kzk.gov.mk/category/ godishni-izveshtai/], Accessed 22 March 2021

91 The Report on the work of the Commission for Protection of Competition is not available on the web site [http://kzk.gov.mk/category/godishni-izveshtai/], Accessed 22 March 2021

92 The Report on the work of the Commission for Protection of Competition is not available on the web site [http://kzk.gov.mk/category/godishni-izveshtai/], Accessed 22 March 2021
} 
Internet and digital platforms. In order to create a picture regarding the degree of digitalization of business in $\mathrm{BiH}$, part of the research is focused on assessing the importance of digitalization and knowledge of business determinants in terms of digitalization by companies in $\mathrm{BiH}$ using data from projects of the Foreign Trade Chamber of $\mathrm{BiH}$ and UNDP BiH. Studies show that the main obstacles hindering the digitalization process of companies are the following: lack of digital skills of the workforce, lack of technical knowledge for further progress of the digitalization process and lack of or access to finance. On the other hand, many have used COVID-19 crisis as a catalyst for a future-oriented recovery. The aim of the paper was to examine, through a comparative and analytical method using the SPSS program, how the pandemic affected the work of the Council of Competition as the authority responsible for the enforcement of competition law in $\mathrm{BiH}$. In order to achieve this goal, a survey was sent to the competition authorities of Bosnia and Herzegovina, Serbia, North Macedonia, Kosovo, Croatia, Montenegro and Slovenia. Six respondents responded to the survey, four from $\mathrm{BiH}$ and two from Serbia, which is not a reference sample. However, the question of the cause of such a weak response may be raised. One of the answers may be the fact that during COVID-19 pandemic, the working conditions in these selected competition authorities were changed and that their employees due to the volume of work did not have time to fill in the survey for which the required time is 20 minutes. Another reason may be that the scope of work and activities is such that in the targeted competition authorities for the protection of market competition, the contribution to scientific research is not on the list of priorities. From the answers that arrived, it is clear that the need to change the organization and work of competition authorities in order to better address the resolution of competition issues in terms of market and economy digitalization.

\section{REFERENCES}

\section{BOOKS AND ARTICLES}

1. Akman P. Online Platforms, Agency, and Competition Law: Mind the Gap. Fordham Int'l LJ, Vol. 43, No 2, 2019

2. Burks J.; Šipragić M.; Bogunović S., Information and communication technology - fuel for SME competitiveness, Deutsche Gesellschaft für Internationale Zusammenarbeit (GIZ), Sarajevo, 2019

3. Honoré P.; Verzeni R., Competition law in the digital economy: a French perspective, Antitrust \& Public Policies, Vol 4, No 2, 2017

4. Imamović Čizmić K.; Sabljica S., Legal and Politological Aspects of Competition in Bosnia and Herzegovina as a Paradigm of the European Integration Process, European Integration Studies, No. 14,2020 
5. Imamović-Čizmić $\mathrm{K}$, The modalities of legal regulation of market competition and their use in the economy of B\&H, Faculty of Law, University of Sarajevo, 2012, doctoral dissertation, pp. 309-313

6. Imamović-Čizmić K., Digital economy, new concepts of competition of economic entities and challenges to competition law and policy, Yearbook of the Law Faculty of the University of Sarajevo, LXIII, 2020

7. Jashari E., The impact of COVID-19 on digital transformation, Digital transformation - a pillar of economic recovery, Kosovo Chamber of Commerce and Konrad Adenauer Foundation, 2020

8. Kehal S.H; Singh P.V., Digital Economy: Impacts, Influences and Challenges, Idea group publishing, 2005

9. Šonje V., Procjena socioekonomskog učinka krize izazvane pandemijom bolesti COVID-19 u Bosni i Hercegovini, in: Vuković V.; Hadžialić H. (eds.), Book 4: Alliance of Small e-Economy in Bosnia and Herzegovina, Edition: Digital Transformation of BiH, Foreign Trade Chamber of BiH Sarajevo, 2020

10. Trifković M., Defining monopolistic agreements of laws in Bosnia and Herzegovina and European Union, Pregled - Journal for Social Issues, Vol. 4, LXXXVI, 2006

\section{LIST OF NATIONAL REGULATIONS, ACTS AND COURT DECISIONS}

1. Decision of the Constitutional court of $\mathrm{BiH}$ in case no. U 25/14

2. Law on Administrative Procedure of Bosnia and Herzegovina, Official Gazette of BiH No. $29 / 02$

3. Law on Competition, Official Gazette of BiH No. 48/05, 76/07 and 80/09

\section{WEBSITE REFERENCES}

1. BiH Chamber of Foreign Trade, UNDP: Notification on activation of tools for assessment of digital performance of companies in Bosnia and Herzegovina (Digital Pulse), [https://www.komorabih.ba/undp-obavijest-o-aktiviranju-alata-za-procjenu-digitalnih-performansi-kompanija-u-bosni-i-hercegovini-digitalni-puls/], Accessed 25 March 2021

2. Council of Competition of Bosnia and Herzegovina, Competencies and organization, [http:// bihkonk.gov.ba/nadleznosti-i-organizacija], Accessed 10 April 2021

3. Crémer, J.; de Montjoye, Y-A.; Schweitzer, H., Competition Policy for the digital era, Final report. Luxembourg: Publications Office of the European Union, 2019, [https:/www. bibsonomy.org/bibtex/2f87b8251c8f49b69fd7bddedec8a7a49/meneteqel], Accessed 15 March 2021

4. Foreign Trade Chamber of Bosnia and Herzegovina, Digitalna komora, Vrata u budućnost, [https://www.komorabih.ba/?s=digitalna+komora], Accessed 01 April 2021.

5. Oslobođenje, Digitalizacija društva je nasušna potreba, [https://www.oslobodjenje.ba/vijesti/ bih/digitalizacija-drustva-je-nasusna-potreba-418240], Accessed 31 March 2021

6. Reports on the work of the Agency for Protection of Competition of Montenegro, [http:// www.azzk.me/jml/index.php/ostala-dokumenta/izvjestaji/izvjestaji-o-radu], Accessed 22 March 2021 
7. Reports on the work of the Croatian Competition Agency, [http://www.aztn.hr/godisnjaizvjesca/], Accessed 22 March 2021

8. Reports on the work of the Commission for Protection of Competition of the Republic of Serbia, [http://www.kzk.gov.rs/izvestaji], Accessed 22 March 2021

9. Reports on the work of the Commission for Protection of Competition of the Republic of North Macedonia, [http://kzk.gov.mk/category/godishni-izveshtai/], Accessed 22 March 2021

10. Reports on the work of the Council of Competition of Bosnia and Herzegovina, [http:// bihkonk.gov.ba/], Accessed 21 March 2021

11. Reports on the work of the Slovenian Competition Protection Agency, [http://www.varstvokonkurence.si/en/activities-of-the-agency/reports-and-activities/], Accessed 22 March 2021

12. UNDP $\mathrm{BiH}$ in cooperation with the Luxembourg Chamber of Commerce, About us, [https://www.digitalnaekonomija.ba/bs-Latn-BA/about], Accessed 12 April 2021

13. Van Gorp, N.; Batura, O., Economic and scientific policy: Challenges for Competition Policy in a Digitalised Economy Study, Directorate general for internal policies policy department, 2015, [https://www.europarl.europa.eu/RegData/etudes/STUD/2015/542235/IPOL_ STU(2015)542235_EN.pdf], Accessed 15 March 2021

14. World bank, GDP per capita, [https://data.worldbank.org/indicator/NY.GDP.PCAP. CD?view=chart], Accessed 01 April 2021

15. World Economic Forum, White paper: Competition Policy in a Globalized Digitalized Economy, 2019, [http://www3.weforum.org/docs/WEF_Competition_Policy_in_a_Globalized_ Digitalized_Economy_Report.pdf], Accessed 15 March 2021 